\title{
SZÉKESFEHÉRVÁR, ROMKERT - 1936-1938
}

\author{
LŐVEI PÁL*
}

Az 1930-as évek székesfehérvári munkálatait műemlékvédelem-történeti szempontból máig nem vizsgálta senki, és ez a mostani, rövid összefoglaló sem lett volna lehetséges, ha a közelmúltban nem készített volna Kovács Klára egy részletes áttekintést a Műemlékek Országos Bizottsága irattárának vonatkozó anyagairól, és nem rendezte volna Bozóki Lajos jól használható tervtári állaggá a kiterjedt Luxhagyatékot.

1934-ben, amikor szakhivatalként újjászervezte a Múemlékek Országos Bizottságát, Gerevich Tibor már évek óta az ország egyik irányadó kultúrpolitikusaként tevékenykedett a képzőmüvészeti élet megújításán. A következő néhány év megmutatta, hogy a múemlékvédelem átszervezését is világos, elméletileg és tudományosan is megalapozott, a korszerü külföldi törekvésekkel konform programmal kezdte. 1943-ban közzétett megfogalmazása szerint: „A szinte naponta adódó müemléki munkálatok, a múemlékvédelem folyómunkái mellett - amelyek sokszor előre nem látható módon s majdnem mindig halasztást nem türve jelentkeznek - a nagyobb szabású munkák több évre előirányzott, átgondolt program szerint folynak. Kisebb-nagyobb évkörök keretében néhány, egymással kor- és stílusbeli, topográfiai stb. szempontok alapján összefüggö, kiemelkedő munkát helyezünk az élre. Így kerültek egy ciklusba az esztergomi és a székesfehérvári ásatások, a veszprémi Gizella-kápolna helyreállítása; ez utóbbi, valamint a jáki apátsági és a veleméri templom, továbbá a feldebrői altemplom falképeinek restaurálása, a pécsi és a szombathelyi ókeresztény feltárások ...". 1

A MOB frissen kinevezett elnökének a szerencse is a kezére játszott: az esztergomi maradványok előkerülése 1934-ben még az előre nem látható módon jelentkező múemléki munkák kategóriájába tartozott, hiszen csupán a várfalról a

\footnotetext{
* Kulturális Örökségvédelmi Hivatal. Tel.: 225-4914; fax: 225-4897

1 Gerevich Tibor: [Előszó.] In: Dercsényi Dezső: A székesfehérvári királyi bazilika. Budapest, 1943. V.
} 
mélybe esett kövek miatt a falkorona biztosítását tűzték ki először célul, az azonban, hogy a váratlanul előkerült leletek lehetőségével a MOB és - hozzáteszem az ország élni tudott, munkatársai lelkes munkáján kívül elsősorban Gerevich Tibornak volt köszönhető, annak, ahogy politikai és kultúrpolitikai kapcsolatait, tudományos tekintélyét - példamutató vezetői erényekről téve tanúbizonyságot - az általa irányított intézmény és ügy érdekében ebben a konkrét esetben, de más esetekben is, hasznosítani tudta.

Székesfehérvár már a tervszerú munkák közé tartozott. Szent István halálának közelgő 900. évfordulója tette lehetővé a királyi bazilika Henszlmann Imre által kiásott majd visszatemetett romjainak újrafeltárását, és újabb területeket is be lehetett vonni a kutatásokba. A költségek megoszlottak a Vallás- és Közoktatásügyi Minisztérium és a város között. ${ }^{2}$ A miniszteri kapavágásra 1936. április 16-án került sor, az érdemi munka április 29-én kezdődött, és az első ásatási szezon november 6-ig tartott. 1937-ben május 10-én indult újra a feltárás, ami augusztus elején fejeződött be, de már június 8-án elkészült a teljes ásatási területet és környezetét dokumentáló légifelvétel. ${ }^{3}$ Ezt követően már a kerítés, a kőtár és a Szent Istvánmauzóleum alapozási és falazási munkái folytak. ${ }^{4}$ A helyi ásatásvezető Kiss Dezső építészmérnök volt. ${ }^{5}$

Már az első ásatási szezon végén, 1936. december 4-én kérte Gerevich, hogy a vallás- és közoktatásügyi miniszter a székesegyház romjait és a közelükben feltárt egyéb építészeti maradványokat az 1881. évi XXXIX. t.c. értelmében nyilvánítsa múemlékké. ${ }^{6} \mathrm{~A}$ „fenntartandó” múemlékké nyilvánítás még december 18-án meg is történt. ${ }^{7}$

Röviddel később, 1937. január 9-én kelt - Gerevich Tibor 11-én írta alá - a miniszternek szóló, a teendőkkel kapcsolatos felterjesztés. ${ }^{8}$ Eszerint ,,az egész környék rendezése ... oly módon eszközölendő, hogy régészetileg, történetileg, múvészileg és hangulatilag, továbbá a térbeli követelmények szerint is egységes

2 MOB 395/1937, 479/1937. sz. iratok (OMvH Könyvtár).

3 Egy eredeti pozitívja az Országos Múemlékvédelmi Hivatal Magyar Építészeti Múzeumában található, Kiss Dezső helyi ásatásvezető ásatási felvételeinek nagyításaival együtt. A fénykép hátoldalán rápecsételt rubrikákban olvashatók a felvétel készítésének adatai, eszerint a fényképész Jokuthy Albert hadnagy volt, és a repülőgépet Bozsóky Sándor pilóta vezette. (Köszönettel tartozom Prakfalvi Endrének, aki a leltározatlan fényképanyagra felhívta a figyelmemet.) A fényképet közölte: Dercsényi, i. m. 2. kép.

4 Dercsényi, i. m. 12-14.

5 Nevét az Építészeti Múzeumban őrzött, részben általa készített ásatási fényképfelvételek feliratai is említik (1. a 3. jegyzetet), de mint ,,vezető mérnök” szerepel az ásatási beszámolóban is: Dercsényi, i. m. 14.

6 MOB 787/1936. sz. irat (OMvH Könyvtár).

7 MOB 4/1937., a miniszteri határozat száma: 15.104-III/1936, 1. még: Dercsényi, i. m. 14.

8 MOB 19/a/1936. (!) sz. irat (OMvH Könyvtár). 
kép álljon elő, aminek alapeleme és központja maga a Szent István-bazilika maradványa. A különálló és különböző korokból származó kőtöredékek az ásatások színhelyén e célra létesítendő múzeumban (lapidarium) állítandók fel. Tudományosan, de szemléletileg és turisztikailag is helyes, hogy a helyszínen, a lelőhely közelében nyerjenek elhelyezést. ... A kőmúzeum célszerü, de a régi korstílusra utaló építmény lenne ... az ásatásokkal és az előkerült maradványokkal összefügg a környező terület és városrész összehangolásának és rendezésének, valamint az ásatások folytán megbontott forgalomnak több vonatkozásban mérlegelendő kérdése."

Már ezt megelőzően, lényegében a feltárások megindulásakor lépéseket tett a MOB a napvilágra kerülő maradványok építészeti terveit majdan elkészítő építész kijelölésére. A neki írt felkérésre adott, 1936. június 9-i válaszában Kotsis Iván műegyetemi tanár, aki egyébként Székesfehérváron ebben az időben kiterjedt építési és városrendezési feladatokat oldott meg máig ható érvénnyel, tudatta, hogy „hozzáértés hiányában a tudomására jutott feladattal (múemlék restaurálása és konzerválása) nem foglalkozhat". ${ }^{9}$ Rajta kívül még Sándy Gyula műegyetemi tanár neve jelenik meg az iratokban, őt azonban a minisztérium szerint ,a püspöki palota ásatások által érintett részének statikai szempontú vizsgálatával és a további intézkedések javaslatával" kellene a MOB-nak megbíznia. ${ }^{10}$

Az új építészeti elemekkel kapcsolatos, rendelkezésre álló tervanyag ${ }^{11}$ szignált része végül Lux Kálmán, a MOB építészeti fôtanácsosa aláírását viseli, és a miniszteri jóváhagyást - Hóman Bálint aláírását - tartalmazó tervlapokon megjelenik Lux Kálmán fiának, a Műegyetemen tanító Lux Gézának aláírása is. Gerevich Tibor és Dercsényi Dezső későbbi híradása szerint azonban a terveket valójában Lux Géza készítette, ${ }^{12}$ ebben nincs is okunk kételkedni. Az építési program stiláris igazodásának jellemzésére megemlítendő, hogy a MOB elnöke 1937. május 31-én kérte a miniszter hozzájárulását, hogy Lux Kálmán és Géza itáliai tanulmányútjának költségét az ásatásokra engedélyezett hitel terhére számolhassák el. „Az út célja, hogy a székesfehérvári ásatások tervezett bemutatása okán a koraromán téglaépítmények felületi kezelését [ezen a falrakás és a díszítés módja értendő - L.P.] a helyszínen tanulmányozhassák". ${ }^{13}$ Június 26-án arra a változtatásra kértek engedélyt, hogy Lux Kálmán helyett Genthon István, a MOB előadója utazhasson. ${ }^{14}$

9 MOB 448/1936. sz. irat (OMvH Könyvtár).

${ }^{10}$ MOB 464/1936. sz. irat (OMvH Könyvtár).

${ }^{11}$ Az alább szereplő valamennyi terv az Országos Múemlékvédelmi Hivatal tervtárában, a Lux-hagyaték Székesfehérvár fiókjaiban található.

${ }^{12}$ Gerevich, i. m. VII.; Dercsényi, i. m. 65.

${ }_{13}$ MOB 310/1937. sz. irat (OMvH Könyvtár).

14 MOB 388/1937. sz. irat (OMvH Könyvtár). 
A legkorábbi tervek még azzal számoltak, hogy a püspöki palota kertjéből nem sikerül megvásárolni a kívánt részt, valamint a kiugró bástya közrefogta bővület se lesz bevonható a romkertbe, ezért a tervezett lapidárium közvetlenül a bazilika négyzetes északkeleti mellékterétől indult volna a kerítés mentén, lényegében a Mátyás-kori keleti épületbővítés hosszában (1. kép). A bazilika déli sávja fölött húzódó utat egy félköríves kapuzaton keresztül vezették volna, amely a Szent István sírkápolnájának tartott, valójában jóval későbbi, román kori kápolna néhány kvádersornyi apszisa helyén rekonstruált kis templom diadalívének vonalához kapcsolódott (2. kép). Ez az újjáépítési gondolat talán még Lux Kálmántól származott, aki korábban, szinte a semmiből, a margitszigeti premontrei templomot is kiépítette. A terv többi része azonban a későbbi együttesnek már a legtöbb lényegi részét tartalmazta: félköríves árkádsor mögé szervezett kőtárfolyosó, hármas árkáddal megnyitott mauzóleum keresztirányú harangfallal, a haranghelyek íves áttöréseivel. Egy tervváltozaton a mauzóleum felmagasítása is látható már.

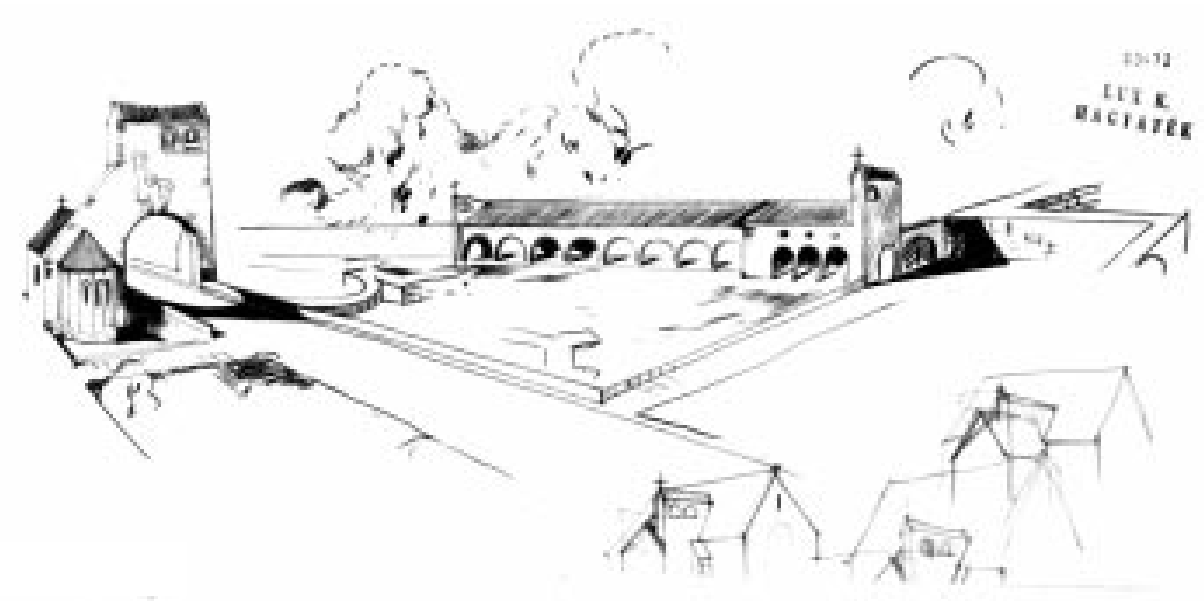

1. ábra. A székesfehérvári romkert rendezésének legkorábbi tervvázlata (feltehetően 1936). OMvH Tervtár, ltsz. 03472. (Lux-hagyaték) / OMvH Fotótár, 170088. neg.

A Gerevich-től idézett forgalomszervezési problémák megoldási javaslatát egy a fehérvári belváros középső részét átfogó vázlat tartalmazza, eszerint a Várkörút és a mai Táncsics Mihály utca között egy új átjárót nyitottak volna. A bazilikától délre elterülő háztömbökben bizonyára szükséges lett volna bontásokat-kiigazításokat végezni, viszont a mai forgalomszervezési gondok elmaradtak volna, és feltehetően ma is állna a Várkörút szemközti oldalán a város monumentális zsinagógája, hiszen a részben a helyén nyitott főutat nem lehetett volna belvárosi utcához kapcsolni. Ehhez a tervegyütteshez már a bástyafal menti, L alakban törő kőtár tar- 


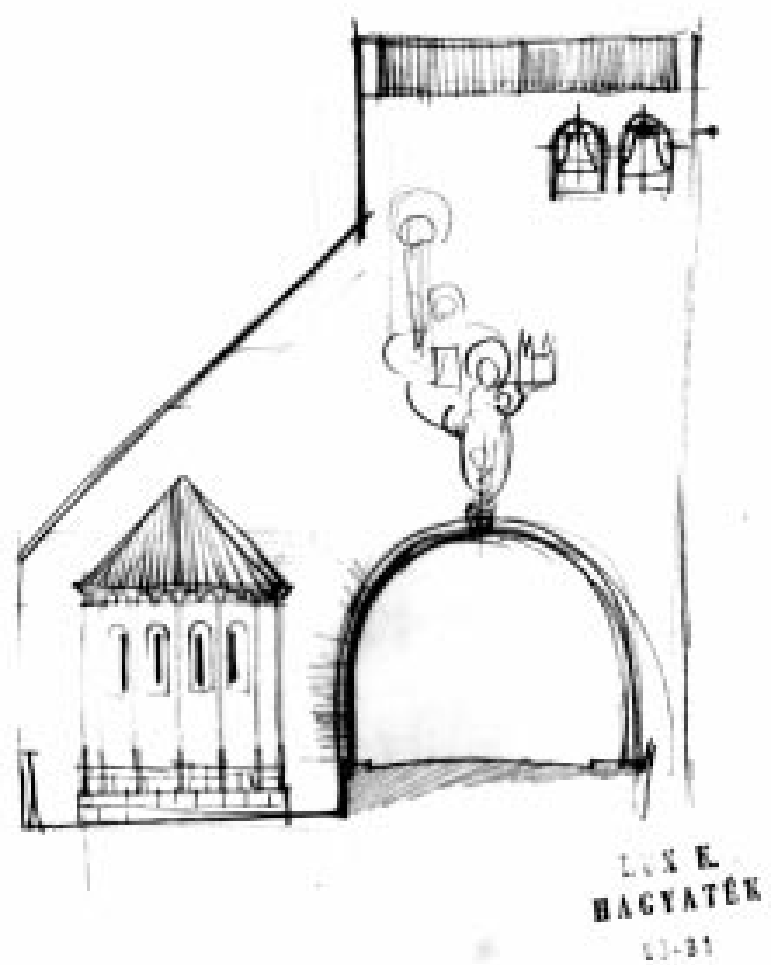

2. ábra. A román kori déli kápolna rekonstrukciójának és a hozzákapcsolt kapunak a vázlata (feltehetően 1936). OMvH Tervtár, ltsz. 03481. (Lux-hagyaték) / OMvH Fotótár, 170105. neg.

tozik, a maihoz képest még túlságosan alacsony, nyílásrendszerében szétesőbb mauzóleummal. A romkert bejárata a Várkörútról nyílt volna, a romok felé csatlakozó, széles lépcsővel, mellette pedig csak egy a gyalogos forgalmat átvezető nyílás és a déli házfal mentén húzódó járda készült volna (3. kép). A mauzóleumban már megjelenik a lépcsős posztamensre állított Szent István-szarkofág. A rajzi ábrázolás technikája már jelzi a később megvalósult, keskeny téglás falazási technikát.

Az új utca megnyitására nyilván nem volt mód, így a következő fázisban a romkert rácsos kapuzatát derékszögben befordították, a széles lépcső pedig a mauzóleum elé került. A mauzóleum ezáltal szembenézetben monumentálisabb megjelenést nyert, a bejárat hatása azonban lecsökkent (4. kép). Hamarosan megjelent a mauzóleum végleges, hármas ablakcsoportja, fokozatosan egyszerúsödött a pillérek kialakítása. Röviddel később az együtteshez az utca átvezetését és egyben a belváros látképi lezárását szerencsésen megoldó hármas kapumotívumot kapcsoltak (5. kép), ez azután dél felé még egy további átjáróval és egy alacsony, négyze- 


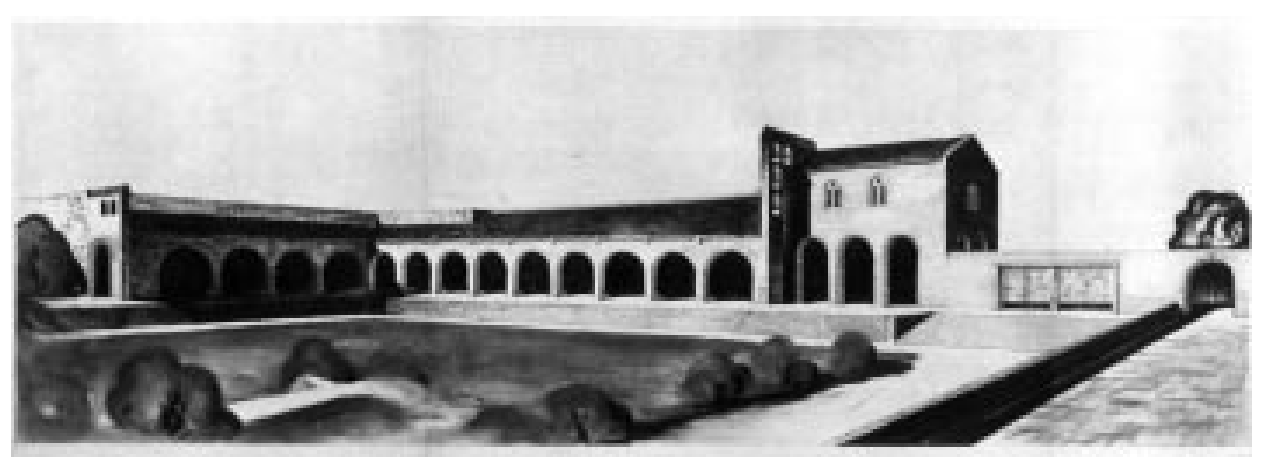

3. ábra. A mauzóleum és a kőtárépület távlati képe a második tervfázisban (1936-1937). OMvH Tervtár, 1tsz. 03804. (Lux-hagyaték) / OMvH Fotótár, 154927. neg.

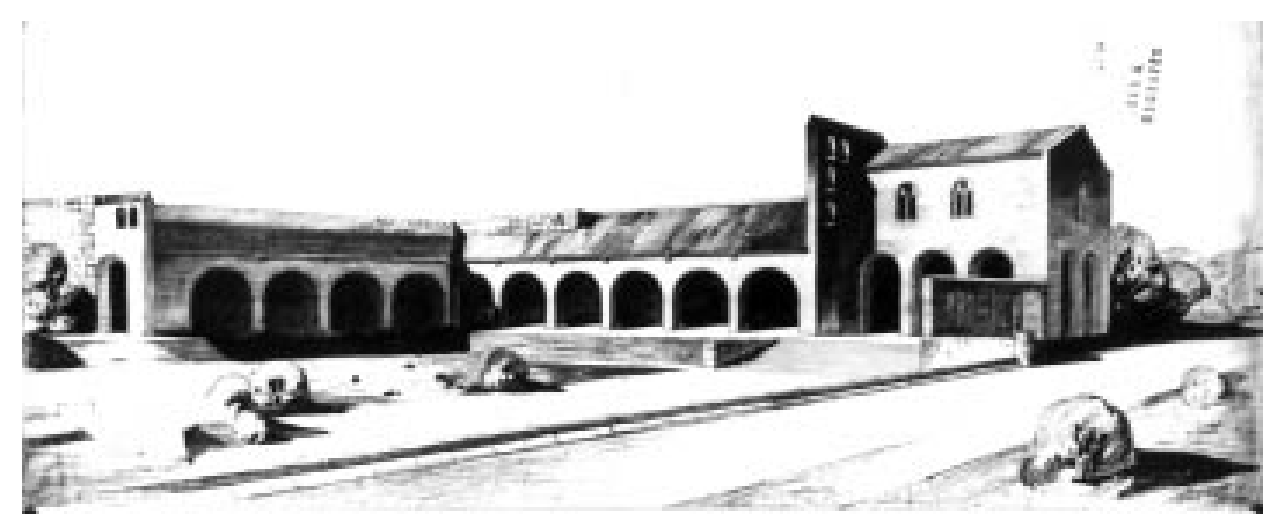

4. ábra. A mauzóleum és a kőtárépület távlati képe a harmadik tervfázisban (1936-1937), Lux Kálmán szignójával. OMvH Tervtár (Lux-hagyaték) / OMvH Fotótár, 171689. neg.

tes toronyelemmel (a már ott lévő transzformátorház befogadására) bővült (6. kép). Ez az a tervfázis, amely végül engedélyezésre került: 1937. június 18-i dátummal viseli a miniszter jóváhagyó aláírását. Ekkor már a román kori kis kápolna lemélyített környezetét csak egy kis harangfallal és feliratos vasráccsal lezárt lépcsővel jelezték, nagyon finom módon. A püspökkert felőli kerítést szokatlan, mintás téglarakású hátfalával a kisebb kőfaragványok elhelyezésére is alkalmassá tették. A tervekhez utoljára kapcsolódó jelentősebb változás a csontmaradványokat őrző kripta elhelyezése. Az egyszerü, domború kereszttel tagolt fedlap a széles lépcső fölött magasodó, a bazilika tengelyében álló mauzóleum együtteséhez szervesen kapcsolódik. 


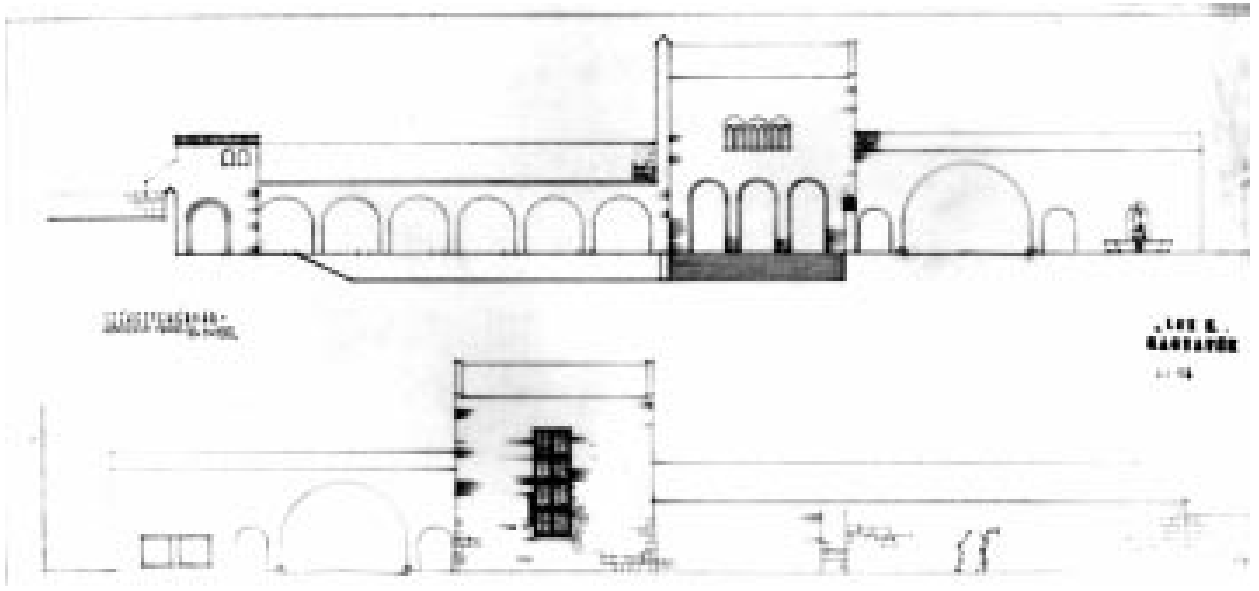

5. ábra. A mauzóleum és a kőtárépület homlokzati tervei a hármas kapuval (feltehetően 1937). OMvH Tervtár, ltsz. 03466. (Lux-hagyaték) / OMvH Fotótár, 154913. neg.

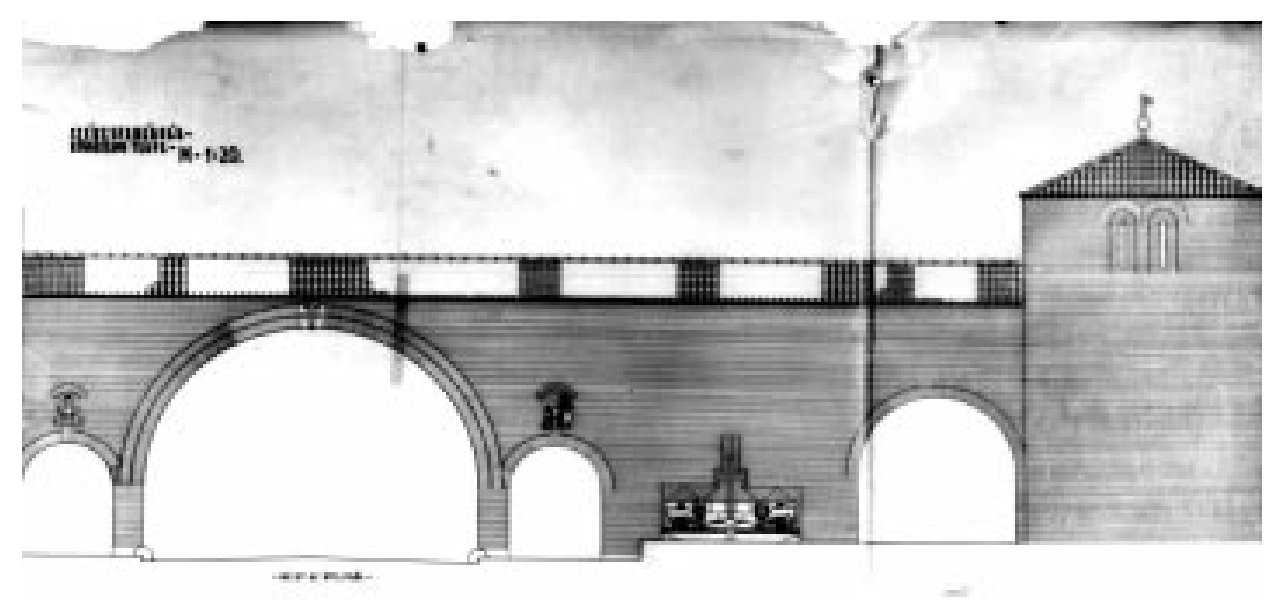

6. ábra. A mauzóleumhoz kapcsolódó hármas kapu és az alacsony torony romkertre néző homlokzatának terve (1937). OMvH Tervtár, ltsz. 1332. / OMvH Fotótár, 170055. neg.

A költségek csökkentése is az oka lehetett annak, hogy a tervek díszítő részletei idővel egyszerüsödtek vagy elmaradtak, ahogy a harangok megvásárlására sem került sor. ${ }^{15}$ Ami végül elkészült, így is a korszak hivatalos képzőmúvészetének

${ }^{15}$ MOB 539/1937. sz. irat (OMvH Könyvtár): Gerevich Tibor előterjesztése a további költségekről, már a megkezdett építési munkálatok idején, 1937. szeptember 27-én. „A kőmúzeum tervei egy szerényebb és egy teljesebb változatban is készen vannak. (A nagyszabásúbb: $102.166 \mathrm{P}$, a szerényebb változat: 46.107 P.)" 
egyik legreprezentatívabb együttese. Aligha véletlen, hogy többnyire a Gerevich Tibor nevével fémjelzett római iskola prominens képviselői múködtek közre. A munkába való bekapcsolódásuk kezdete 1937 szeptemberében dokumentálható: Aba Novák festette a mauzóleum falképdíszét (1938-ban csak az északi fal készült el, a déli és keleti 1940-ben), ${ }^{16}$ Sztehlo Lili müve a keleti nagy üvegablak, ${ }^{17}$ és Madarassy Walter készítette a téglafalakba helyezett kődombormúveket és körablakokat. ${ }^{18}$ A kőfaragványok terveit azonban Lux Géza rajzolta, ${ }^{19}$ ami a körablakok jellegzetes középkorias motívumkezelésére is magyarázatot ad. Az ablakrácsok ugyancsak Lux Géza rajzai alapján készültek. ${ }^{20}$

Gerevich később a királyi bazilikáról Dercsényi Dezső által írt monográfia előszavában értékelte a munkák eredményeit (7. kép). „A fehérvári ásatásoknál követett eljárás a helyi adottságokból, a feltárt leletek természetéből folyt, s lényegesen különbözött a hasonló időben végzett esztergomi ásatásainktól. ... Esztergomban nagyobb, egymással összefüggőbb épületmaradványok kerültek elő a föld alól; megvolt a lehetősége annak, hogy némi kiegészítéssel az eredetit helyreállítsuk, anélkül, hogy romantikus elképzeléshez kellett volna folyamodni, régebben, sajnos gyakran véghezvitt müemléki hamisítás végzetes hibájába esni. Kisebb mérvü kiegészítést is csak olyan helyen végeztünk, ahol biztosan következtethettünk, s ahol azt a szerkezet nélkülözhetetlenné tette; ezt is olyan anyaggal, amely feltűnően elüt az eredetitől s így bárkitől és bármikor megkülönböztethető. Az esztergomi királyi palota olyan helyiségeit, amelyek falainak és boltozatainak kiegészítésére nem került elő elegendő töredék, ... muzeálisan, mintegy vitrinszerűen, egyszerű és praktikus lapos, modern üvegfödémmel zártuk le. A helyhez nem köthető töredékek természetesen ... egyszerüen képzett kőtárba kerültek, s lemondtunk az építész számára talán csábító, de régészetileg hamis rekonstruálási kísérletekről. A székesfehérvári bazilika falai, nem is mindig összefüggően, csekély magasságban kerültek elő. A felépítmény szinte teljesen elpusztult, a szerkezeti vagy díszítő töredékek, eredeti helyüknek többnyire teljes ismeretlenségében, mint csonka tagok szóródtak szét. Itt tehát a feladat az egy-két méternyi magasságú falmaradványok biztosítására és a töredékek mennél teljesebb összegyüjtésére, áttekinthető elrendezésére és rendszerezésére szorítkozhatott. Hogy a felszínre került hézagos falmaradványok egységesebb, a szemnek is kellemesebb képet nyerjenek, az ásatási területet kertesítettük." 21

\footnotetext{
${ }^{16}$ MOB 533/1937. sz. irat (OMvH Könyvtár), Dercsényi, i. m. 68.; 13-14. kép.

${ }^{17}$ MOB 532/1937. sz. irat (OMvH Könyvtár), Dercsényi, i. m. 72.; 15. kép.

${ }_{18}$ MOB 530/1937. sz. irat (OMvH Könyvtár), Dercsényi, i. m. 72.; 16. kép.

${ }^{19}$ Dercsényi, i. m. 72.

${ }^{20}$ Gerevich, i. $m$. VII.; Dercsényi, i. $m .72$.

${ }^{21}$ Gerevich, i. m. VII-VIII.
} 


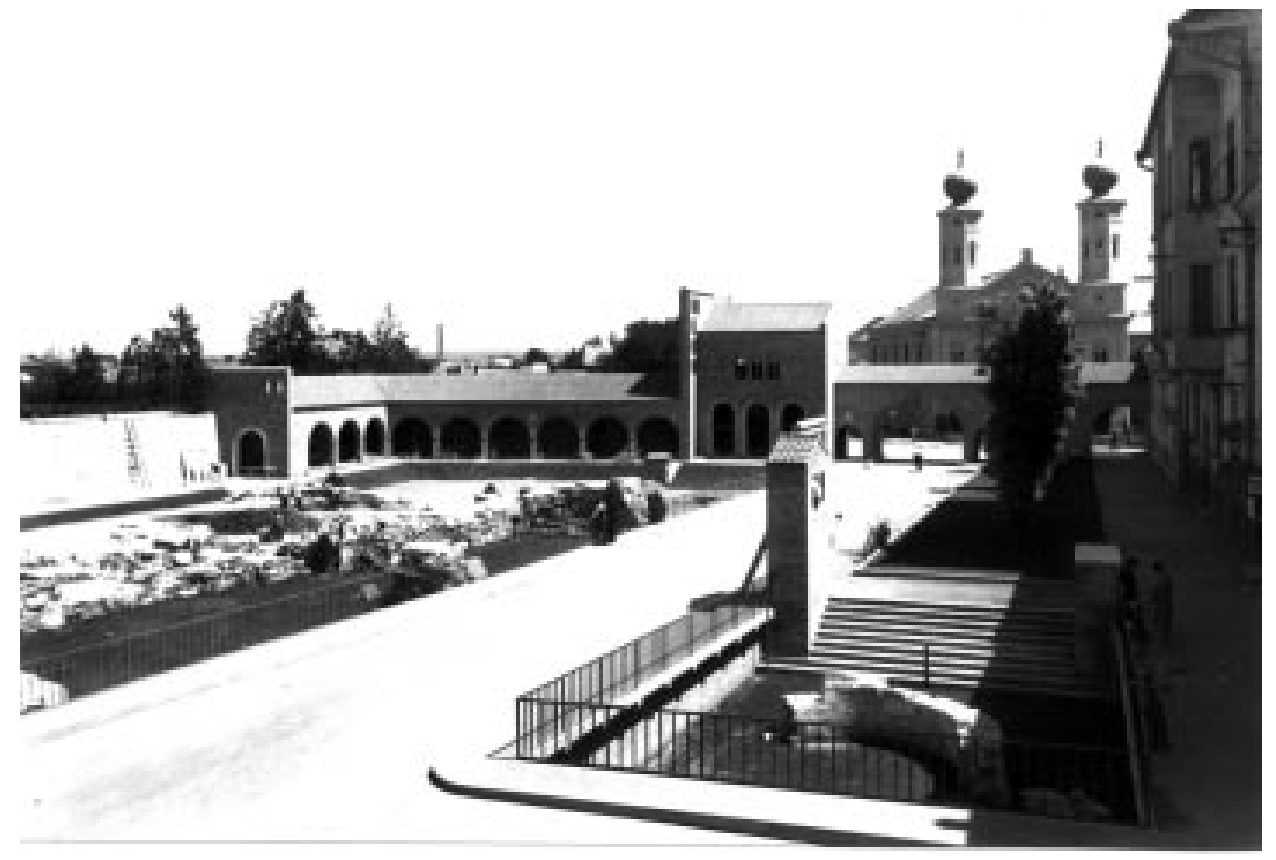

7. ábra. A székesfehérvári romkert az 1938-as befejező munkálatok idején. OMvH Fotótár, 1644. neg.

A későbbi változtatások elsősorban a romterületet érték. Az 1960-as évekbeli ásatások - részben szakítva a korábbi elképzelésekkel - olyan finom részletek, márványpadlók bemutatását is célul tűzték ki, amelyek az időjárás viszontagságait végképp nem bírták, átértelmezték a Mátyás-kori bővítés falvonulatait, fokozatosan megbontva a falmaradványok és a zöldfelület egykori kertészeti egyensúlyát. Területileg erősen megnövekedett a déli kápolnák bemutatása, mára teljesen eltűntek a Lux-féle helyreállítás ottani járulékos elemei. Az utóbbi években előbb restaurálták-újrafestették Aba-Novák korábban elfedett falképeit, ennek védelmére üveg került a hármas bejárati ívbe, majd megtörtént a mauzóleum és a kőtár épületének helyreállítása is. ${ }^{22} \mathrm{Az}$ erős építészi késztetés ellenére sikerült megakadályozni a kőtár árkádsorának beüvegezését, amely új és kedvezőtlen elemet vitt volna be az együttesbe, erősen csökkentve annak a fény-árnyék hatásokkal játszó, mediterrán jellegét. Állagvédelmi okokból megszünt a kőtár kiállítása is. Ellenkezésünk ellenére értelmetlen módon kicserélték a kőtárfolyosó téglapadlóját, más méretủ és felületi hatású téglákal - a mauzóleumban még ott az eredeti a szarkofág

${ }^{22}$ A terveket Oltai Péter készítette. 
lépcsős téglaposztamensével együtt - véleményem szerint hozzájuk sem szabad nyúlni! Az együttes finoman archaizáló, nemesen egyszerű formaképzésébe szervesen illeszkedő kriptafedlap helyére az ezeréves történelem eseményeit megörökítő, részletgazdag bronz alkotást elképzelő városi vezetés és építésztervező ellenében egyelőre még sikerült megtartani az eredeti lapot, igaz, a kereszt egyik szárának megcsonkításával arányai azért kedvezőtlenül változtak.

A székesfehérvári romkert a későbbi - sosem a múemlékvédelem által kezdeményezett - feltárások során, a kedvezőtlen környezeti hatások következtében is, már visszafordíthatatlan módon elvesztette 1938-as képét. A kőtár-mauzóleum együttese azonban áll, egyik legfontosabb példájaként az 1930-as évek múemléki elveit tükröző építkezéseknek, egyben a hivatalos állami építészeti-müvészetivárosrendezési elképzeléseknek. A háború végén fiatalon elhunyt Lux Géza egyetlen monumentális alkotásaként ma már önálló jogon is múemléknek tekinthető és tekintendő, annak minden módszertani megkötöttségével. Tágabb összefüggésekben is szemlélhető: a két világháború közötti, hivatalos állami múvészet Szeged mellett legfontosabb nagy együttesét jelentő Székesfehérvár sikeres városképi megoldásaihoz stilárisan és szellemiségében is szervesen kapcsolódik. A belváros lezárása, az egykori várfal pótlása szempontjából ma még fontosabb az együttes, mint építésekor volt: takarja a mögötte lévő területet, amely a zsinagóga elpusztításával és a szálloda, áruház, autóparkoló, széles útpálya együttesének kialakításával széteső, sivár városképet eredményezett közvetlenül a történeti belváros szomszédságában.

\title{
SZÉKESFEHÉRVÁR, GARDEN WITH THE RUINS OF THE MEDIEVAL PROVOSTAL CHURCH - 1936-1938 Summary
}

\begin{abstract}
The paper offers a brief survey of the excavations and conservation of the ruins of the medieval provostal church of Székesfehérvár, that took place between 1936 and 1938, in connection with the 900th anniversary of the death of King Saint Stephen I of Hungary, celebrated with large-scale programs in 1938 (the King was the founder of the provostship, which became the place of coronation of the medieval rulers of Hungary, and at the same time the burial-place of Saint Stephen and many of his successors). In this process the art historian Tibor Gerevich, leader of the National Office for the Protection of Historic Monuments played an important role. The building of the so called mausoleum, where the marble sarcophagus from the 11th century, considered as the monument of Saint Stephen was placed in the centre, and a semicircular-arched gallery for the purpose of a lapidary were built on the border of the excavated territory. The buildings were designed by the young architect Géza Lux, in a modest, elegant style referring to the brickwork of some Italian Romanesque churches. The ensemble is an important part of the history of monument protection in Hungary, and at the same time it offers the highest level of the official state architecture of its age.
\end{abstract}

Keywords: Székesfehérvár, garden with ruins, monument preservation 